\title{
CRAFTING HISTORY: \\ ORAL HISTORY PROJECTS, EXPERIENTIAL LEARNING, AND A MEDITATION ON TEACHING AND LEARNING
}

\author{
George White, Jr. \\ York College, City University of New York
}

\section{Introduction}

Oral history has earned a well-deserved place in the academy, especially among professional historians. ${ }^{1}$ This article grows out of an effort to wed the use of oral history to instruction in an entry-level World History course. At its foundation, the project aimed to strengthen students' skills in communication and critical thinking, to deepen student learning of basic course themes, to increase student knowledge of specific facts and events in the course, and to enhance a sense of democratic empathy among the students.

A primary goal of the oral history project was to encourage the students to see themselves as participants, rather than "neutral observers," in the process of understanding and analyzing historical phenomena. ${ }^{2}$ The project created a space within which students could analyze course topics through a critical lens on power and privilege, race, gender, class, and identity. ${ }^{3}$ For students in a general education history survey course, the project was an effort to deepen student learning and foster engaged

\footnotetext{
${ }^{1}$ See, e.g., Elgin Klugh, "Reclaiming Segregation-Era, African American Schoolhouses: Building on Symbols of Past Cooperation," The Journal of Negro Education, 74:3 (Summer 2005), 246-259; Paul Thompson, "The Voice of the Past: Oral History," and Luisa Passerini, "Work Ideology and Consensus Under Italian Fascism," in Robert Perks and Alistair Thomson, eds., The Oral History Reader (New York: Routledge, 1998), 25-32 and 53-62; Kathryn Walbert and Jean Sweeney Shawver, "Oral History in the Classroom" (a guide for K-12 teachers produced by the University of North Carolina at Chapel Hill School of Education), at http://www.learnunc.org; Dr. G. Kurt Piehler's History 439 course "Oral Histories of War and Peace" as currently taught at the University of Tennessee, Knoxville, at http://www.web.utk.edu/ history/faculty/f-piehler.htm. I have to give a "shout out" to Kurt Piehler. For those who don't know, he was the founding director of the Rutgers Oral History Archives of World War II. More immediately, I must thank him for introducing me to the use of oral history in an undergraduate setting and for encouraging me to teach History 489, "Oral Histories of War and Peace."
}

'This author has been heavily influenced by the work of intellectuals like Zora Neale Hurston, Lynn
Abrams, Alan Lomax, and Donald Ritchie. To that end, see, e.g., Zora N. Hurtson, The Complete
Stories (New York: HarperCollins Publishers, 2008); Lynn Abrams, Oral History Theory (New York:
Routledge, 2010); Ronald D. Cohen, ed., Alan Lomax: Selected Writings, 1934-1997 (New York:
Routledge, 2003); Alan Lomax, The Land Where the Blues Began (New York: The New Press, 2002);
Donald A. Ritchie, Doing Oral History (New York: Twayne Publishers, 1995).

${ }^{3}$ Abrams, Oral History Theory, 5-8; see generally Jack L. Daniel and Marta J. Effinger, "Bosom Biscuits: A Study of African American Intergenerational Communication," Journal of Black Studies, 27:2 (November 1996), 183-200. 
citizenship. Thus, the project was not simply a way of recording personal narratives but a tool with which to decipher the multiple meanings of that narrative, a means of creating new "'mines of raw data' from which [to] extract historical interpretations."

In addition to the scholarly assumptions about the value of oral history interviews, I placed the use of oral history interviews within the context of the extant literature on innovative pedagogy and enhanced learning. As a result, this project also rested on the research of historians and other scholars who champion, in particular, the value of experiential learning. Experiential learning takes place when a student forms a direct relationship with the subject matter. In this atmosphere, knowledge becomes active, teachers become active learners - through their joint experimentation with their students-and students become knowledge creators. ${ }^{5}$ Furthermore, I was responding to a call by scholars who challenged academics to be more pro-active in addressing the well-publicized achievement gap facing students of color. ${ }^{6}$ Consequently, this article is grounded in the scholarly discussions on oral history and effective pedagogy, serves as a complement to the scholarship of Perks and Thomson, Vasquez and Wainstien, and others, and provides a template for other academics to duplicate, discard, or enhance.

\section{Setting Up Shop: The Project Plan}

A growing scholarly consensus maintains that for teaching to be transformative for students, instructors must teach beyond the content of their courses. ${ }^{7}$ For some, it might mean challenging the scholarly and popular consensus about the value or

\footnotetext{
${ }^{4}$ Barbara Allen, "Oral History: The Folk Connection," in David Stricklin and Rebecca Sharpless, The Past Meets the Present (Lanham, MD: University Press of America, 1988), 15-26 (as quoted in Ritchie, Doing Oral History, 16).
}

${ }^{5}$ Lawrence Preiser, "Children in Action: An Experiential Approach in a Psychology Gateway Course," DisCover: A Journal of Scholarly Teaching, 1:1 (2008), 29-41; see also Louisa Yan and David Kember, "Engager and Avoider Behaviour in Types of Activities Performed by Out-of-class Learning Groups," Higher Education, 48 (2004), 419-438; and David R. Huehner and Daniel Kallgren, "Technology and Student-Centered Learning: The University of Wisconsin Student History Network Project," The History Teacher, 33:1 (1999), 41-54.

"James A. Vazquez and Nancy Wainstien, "Instructional Responsibilities of College Faculty to Minority Students," The Journal of Negro Education, 59:4 (Autumn 1990), 599-610.

"Sarah D. Brown, "History Circles: The Doing of Teaching History," The History Teacher, 42:2 (February 2009), 191-204; Ken Bain, What the Best College Teachers Do (Cambridge: Harvard University Press, 2004). I leaned of this school of thought through the York Center on Excellence in Teaching and Learning ("CETL") when I received a Title II grant from CETL to participate in a yearlong research project to use technology to improve student learning. 
importance of certain people, groups, or events. ${ }^{8}$ For others, it might mean creating a classroom environment that pulls students into the material. At least one historian who does work within the realm of the Scholarship of Teaching and Learning ("SoTL") asserts that the best teachers set a tone that helps students to develop both an inquisitiveness and healthy skepticism that allows those students to draw connections and make comparisons. ${ }^{10}$ While laudable goals to which many teachers aspire, developing practical ways in which to implement these goals in the classroom can be difficult. The difficulty is increased in teaching large bodies of students in required courses who might lack enthusiasm for the subject and any real context or understanding of the importance of the issues being presented. The need to create connections between history and the student is particularly critical when teaching students of color and at-risk youth, specifically. ${ }^{11}$

The desire to inspire and to encourage healthy skepticism grounded this effort to develop an oral history project in an entry-level course at my home institution, York College, City University of New York (CUNY). Students at York College who enroll in a survey class in the Humanities often do so in order to satisfy general education requirements for graduation. In my experience, finding ways to motivate these types of students is critical to an effective classroom environment, not to mention disabusing these students of their misconceptions regarding the study of history. ${ }^{12}$ The effort to make the course topics relevant to students is complicated by my students' varied backgrounds and the impulse for them to focus on their differences from each other and their collective difference from the historical subjects and events at issue in the course.

${ }^{8}$ See, e.g., James W. Loewen, Teaching What Really Happened: How to Avoid the Tyranny of Textbooks and Get Students Excited About Doing History (New York: Teachers College Press, 2010).

${ }^{9}$ York CETL provided my introduction to SoTL. This article is based on a smaller think-piece published in the York CETL journal DisCover. The article and the underlying research project benefitted greatly from the discussion, insights, and encouragement I had with and received from my fellow CETL grantees: Aegina Barnes, Emily Davidson, and Leslie Keiler; and especially Michael Cripps, Anamika Dasgupta; Elizabeth Meddeb, Fabiola Fernandez-Salek, Karin Wolf, Detlef Ronneburtger. I also owe a tremendous debt of gratitude to CETL Director Deb Swoboda for her gentle but persistent prodding of us all throughout the process. We were all better because of her intellectual mentorship.

${ }^{10}$ Todd Estes, "Constructing the Syllabus: Devising a Framework for Helping Students Learn to Think Like Historians," The History Teacher, 40:2 (2007), 183-202.

${ }^{11}$ See, i.e., Jawanza Kunjufu, Developing Positive Self-Images and Discipline for Black Children (Chicago: African American Images, 1984); Beverly E. Pringle, James E. Lyons, and Keonya C. Booker, "Perceptions of Teacher Expectations by African American High School Students," The Journal of Negro Education, 79:1 (Winter 2010, 33-40.

${ }^{12}$ David J. Voelker, "Assessing Student Understanding in Introductory Courses: A Sample Strategy," The History Teacher, 41:4 (August 2008), 505-518. 
York College is a senior CUNY college located in Southeast Queens, the community from which it draws a significant number of its students. Queens is a large borough featuring tremendous ethnic, linguistic, racial, and religious diversity. Queens also has the most diverse mix of immigrants in New York City and was reported to be the tenth poorest county among the 62 counties in the State of New York. The students at York reflect this demographic template. At present, our students represent roughly eighty different countries. Many of the students are either immigrants or firstgeneration Americans. A majority of the students are African American, Afro Caribbean, or African. Over sixty percent of our students are female, and "English Language Learners" form another large proportion of the student body. For most, college is a life-changing event and many enroll at York for its business and professional programs, only taking the bare minimum of Humanities courses required for graduation. A good number of York faculty members teach beyond their course material to encourage critical thinking skills and develop competencies that will help our students become engaged citizens. ${ }^{13}$ Furthermore, I find to be salient the recommendations of Professor Deneia Thomas who found that an instructor can strengthen student learning by "using culturally relevant and resiliency skill-building methodologies such as task goals ... tasks that ... may enhance self-sufficiency and motivation, and thereby academic adjustment [to college]."14 Therefore, the oral history project seemed to be a viable response to the imperative of effective teaching for working-class students of color, citizens and immigrants alike.

The desire to marry experiential learning with teaching critical thinking, strong communication skills, and the fundamentals of historical research for a diverse group of entry-level students was distilled into three foundational questions. First, I sought to measure whether students achieve a deeper level of learning as active participants. Second, I sought to discern whether out-of-class learning could strengthen student understanding of course material in a general survey course. Finally, I aimed to determine whether students gain greater empathy for historical subjects through interviews. My hope was to find answers that could lead to a better learning experience for my students. ${ }^{15}$

\footnotetext{
${ }^{13}$ See, e.g., Aegina Barnes and Elizabeth Meddeb, "ePractice Makes Perfect: Online Portfolios and Writing Improvement in English Language Leamers," DisCover: A Joumal of Scholarly Teaching, 2:1 (Fall 2009), 39-58.
}

${ }^{14}$ Deneia M. Thomas, et al., "Self-Efficacy, Motivation, and Academic Adjustment Among African American Women Attending Institutions of Higher Education," The Journal of Negro Education, 78:2 (Spring 2009), 159-171, 167.

${ }^{15}$ See Mary T. Huber and Pat Hutchings, The Advancement of Learning: Building the Teaching Commons (San Francisco: Jossey-Bass, 2005), and Kathleen McKinney, "Attitudinal and Structural 
The oral history project is a prime example of innovative methods of infusing the classroom with experiential learning; it also served as a way to record and preserve histories in marginalized communities. The hope was that students who engaged in the oral history project would gain a deeper understanding of historical themes and controversies if they transacted knowledge with a real person in a real-life setting. ${ }^{16}$ Further, I postulated that oral history interviews were a powerful source of historical narrative; in some ways, these sources can be more useful and compelling than written sources because they articulate a greater scope of emotion and meaningful range than the "monotone of writing." 17 More importantly, it seemed likely that the student volunteers could begin to develop the building blocks necessary for conducting scholarly research. In this regard, the critical thinking and writing skills that the student volunteers would develop could encourage them to consider history as an academic major and would be easily transferable to other fields or professions.

Other scholars and instructors have used oral history projects in their classrooms and published their research results. The purpose and institutional background are what distinguish my study from other oral history projects. Some have used oral history projects in general education courses such as entry-level American history classes. ${ }^{18}$ Others used oral history projects in themed, upper-level classes or with the specific purpose of addressing community histories or creating public history exhibits. ${ }^{19}$ Still

${ }^{15}$ (...continued)

Factors Contributing to Challenges in the Work of the Scholarship of Teaching and Learning," New Directions for Institutional Research, no. 12.9 (Spring 2006), 37-50 (published online in Wiley InterScience at www.interscience.wiley.com).

${ }^{16}$ Leslie A. Schuster, "Working-Class Students and Historical Inquiry: Transforming Learning in the Classroom," The History Teacher, 41:2 (February 2008), 163-178; see also Rina Benmayor, "Narrating Cultural Citizenship: Oral Histories of First Generation College Studies of Mexican Origin," Social Justice, 29:4 (2002), 96-121, 96-98.

${ }^{17}$ Alessandra Portelli, "What Makes Oral History Different," in Perks and Thomson, The Oral History Reader, 64-66. See also Chris Edward, "Putting Life into History: How Pupils Can Use Oral History to Become Critical Historians," Teaching History [Great Britain], 123 (2006), 21-35.

${ }^{18}$ David A. Reichard, "Forgotten Voices and Different Memories: How Students at Cal State University Monterey Bay Became Their Own Historians," Journal of American History, 88:4 (2002), 1467-1471; Pattie Dillon, "Teaching the Past Through Oral History," Journal of American History, 87:2 (2000), 602-605.

${ }^{19}$ Mark Naison, "Hip Hop and Oral History: Turning Students into “Griots of a New Age," $O A H$ Magazine of History, 22:3 (2008), 46-48 [for a course on Hip Hop Culture]; Spencie Love, "Chatham County, Community at the Crossroads: A Southern/African American Oral History Seminar," Journal of American History, 87:2 (March 2000), 614-621; Anne Butler and Gerri W. Sorenson, "Patching the Past: Students and Oral History," Frontiers, 19:3 (1998), 200-231 [regarding women's history]. 
other academics have published work regarding the uses of oral history interviews in non-history courses or outside of higher education, generally. ${ }^{20}$ My oral history project straddled many of these, with its emphasis on deep learning and strengthening students' critical thinking skills. However, it is the only one that was performed in a world history class on a diverse, urban campus.

\section{Assessment}

I decided that I would assess the results of the oral history project at various stages of the semester, and, at each stage, evaluate for relevance, clarity, thoroughness, and organization. ${ }^{21}$ First, I asked students to choose a subject that fit within the themes of the course and to submit a list of questions to me prior to the interview so that I could determine whether the questions were appropriate for the interview subject and whether the questions were crafted to elicit responses on the themes addressed in the course. ${ }^{22}$ I expected students to revise their questions in accordance with the comments I provided.

For the second assessment, I asked students to submit a recording of their interview which I reviewed based on the general criteria noted above, as well as on a number of other factors. This second assessment focused on the tone and trajectory of the interview and included a review of whether the student posed the questions drafted in advance, whether the student provided ample opportunity for the subject to respond fully to the questions, posed appropriate follow-up questions to obtain relevant information, or dominated the interview by talking too much. I evaluated the students on their ability to be sufficiently flexible and adept to allow the interview subject to discuss themes, topics, or events that the student did not anticipate. Thus, part of my

\footnotetext{
${ }^{20}$ Michelle Johansen and Martin Spafford, "'How Our Area Used to be Back Then:' An Oral History Project in an East London School," Teaching History [Great Britain], 134 (March 2009), 37-46; James Culhane and Andrea B. Frantz, "An Interdisciplinary Oral History mitiative," American Journal of Pharmaceutical Education, 71:6 (2007), article 121, 1-6; Rita Irwin and Lorrie Miller, "Oral History as Community-Based Participatory Research: Leaming from First Nations Women Artists," Journal of Cultural Research in Art Education (Fall 1997), 15, 10-12; Sharon Van Oteghen, "Using Oral History as a Motivating Tool in Teaching," Journal of Physical Education, Recreation, and Dance, 67:6 (August 1996), 45-58.
}

${ }^{21}$ For example, see Frank I. Fonsino, "Criteria for Evaluating Oral History Interviews," The History Teacher, 13:2 (February 1980), 239-243; Michael Ebner, "Students as Oral Historians," The History Teacher, 9:2 (February 1976), 196-201; and Robert D. Misevich, "Oral History in Undergraduate Research," The History Teacher, 6:1 (November 1972), 47-50.

23Joan Sanger, "Telling Our Stories: Feminist Debates and the Use of Oral History," in Perks and Thomson, The Oral History Reader, 88-89 (with regard to the need to contextualize oral history interviews). 
interview assessment was an examination of the students' verbal and nonverbal communication skills, assessing the ability of the student to elicit information and draw out the interview subject. ${ }^{23}$

After the completion of the interview process, students were required to write an essay in which the student reflected on the interview and connected it to matters addressed in class. The third and final assessment involved a review of the student's post-interview essay. I evaluated essays based on the student's ability to draw connections between the interview subject and historical figures, events, or phenomena in a way that demonstrated an understanding of the historical events as well as an ability to analyze their meaning in the course of history. In addition, I reviewed the essays for fundamental writing skills, including organization, clarity, grammar, punctuation, and spelling. ${ }^{24}$

\section{Implementation}

The project was implemented in York's "Three Worlds" class, which is a world history course that moves chronologically from $1500 \mathrm{AD}$ to the present. It covers the interaction between the "old worlds" of Africa, Asia, and Europe and the "new world" of the Americas from the period of European exploration to the era of decolonization in the late twentieth century. Because the "Three Worlds" course satisfies a General Education requirement in the College, the students in the class reflect the diversity of the student body and most are not history majors. In a class with such scope and breadth, students encounter a diversity of themes and topics. The predominant themes in the course relate to social stratification based on race, gender, class, the migration and immigration of people seeking economic opportunity, education, religious tolerance, safety, and freedom. Throughout the semester, we explore concepts of citizenship and the relationship between the individual and the state. During the first week of the semester, I announced to the "Three Worlds" class the opportunity to do an oral history project in lieu of taking the course's final examination. I handed to interested students a document describing my expectations for the project. Several students expressed interest and six committed to the project. For the oral history project, I asked student participants to think broadly about course themes as they prepared for their interviews.

\footnotetext{
${ }^{23}$ Ritchie, Doing Oral History, 9, 66-69, 78-79; and Charles T. Morrissey, "On Oral History Interviewing," in Perks and Thomson, The Oral History Reader, 107-113.

${ }^{24}$ Fonsino, "Criteria for Evaluating Oral History Interviews," 240-241.
} 
Having agreed to undertake an oral history interview, the six students - Emile, Idris, Joan, Jorge, Mena, and Reveca ${ }^{25}$ - took an Informed Consent/Deed form to their respective interview subjects for a signature. In addition, each student signed their own Informed Consent/Deed form, granting me permission to use their work in my research project. ${ }^{26}$ Although all of the student volunteers claimed to have experience operating either audio or video recording equipment, most did not own any equipment. As a result, they borrowed equipment from the College and began their investigations. ${ }^{27}$

The diversity of the self-selected students and their subjects fairly mirrored the breadth of topics and issues in the course. The first student, Idris, an African American man, was struck by the synchronicity between the enslavement of Africans for toil in the Americas and the collapse of African self-governance in the late nineteenth century, following hundreds of years of contact with Europe. Because he was convinced that slavery was a form of social control, he entitled his project "From Slavery to Prison." For this project, Idris interviewed a formerly incarcerated individual who had written a book about his own experiences and struggles. Idris' interview subject asserted that the high incarceration rates for Black and Latino women and men could not be explained solely by crime rates or drug use. Indeed, Idris' subject argued that crime rates vary only slightly across racial lines; therefore, the over-representation of people of color in America's jails and prisons reflects an unexamined but institutionalized policy of racialized social control that has dire consequences for the economic, political, and social well-being of the nation. ${ }^{28}$

Joan, a Jamaican American female student, was interested in examining the lives of Muslim women residing in America. Her interview subject was an Irish American woman who had converted to Islam and who currently works in a Muslim non-profit organization. Joan's interview dispelled certain myths that she had regarding Islam and the role of women in Muslim communities. ${ }^{29}$ In fact, Joan drew the conclusion that many of the stereotypes of Islam have more to do with efforts of some Muslims-and Islamophobes - to project a narrow and singular model of Islam as well as the common myths that circulate often freely in the media. In her post-interview essay, Joan indicated that although she understood that fundamentalism was not unique to Islam,

${ }^{25}$ All of the students' names are pseudonyms.

${ }^{26} \mathrm{~A}$ copy of the Informed Consent/Deed is attached as an Appendix.

\footnotetext{
${ }^{27}$ In this regard, I owe a special thanks to Daniel Phelps, instructor in the Department of Performing and Fine Arts and manager of the York College Television Studio, who trained the students on the Collegeowned devices.
}

${ }^{28}$ Idris audio interview.

${ }^{29} \mathrm{Joan}$ post-interview essay. 
she conceded that she had unconsciously inculcated many of the negative ideas most Westerners associate with Muslims. Thus, for Joan, part of the lesson of the interview was that religious tolerance was not just an abstraction but something that had to be lived diligently.

Jorge decided to interview himself-with the help of some of his friends-to discuss the issues of immigration and citizenship. Born in Ecuador, Jorge and his parents migrated to the United States when he was two years old. Although Jorge spoke at some length about the struggles of being a Latino immigrant in the United States, the focus of his interview and response to my post-interview questions centered on his identity as an American. Jorge described his own immigrant experience and countered commonly-held negative stereotypes of the "parasitic immigrant" by professing, among other things, his willingness to work long hours and to serve in the U.S. armed forces. ${ }^{30}$ Jorge acknowledged that his parents came to the United States in defiance of the existing regime of immigration laws, but averred that his immigration status did not change his identity: "Even though I am not a legal American I do feel American because I celebrate all of the American traditions and have been living in this country for 19 out of my 21 years of being alive ... I am used to waking up and taking the train to work, to English being the language I speak and understand perfectly ... In my mind, in my heart I feel I belong to this country.",31

The fourth student, Emile, is the child of Caribbean immigrants. Emile was interested in the experiences of a successful immigrant businessman who had decided to return to his native island of Barbados. In contrast to Jorge's easy association with his "American-ness," Emile's interview subject revealed that despite the career success he had enjoyed in the United States, he still regarded Barbados as his home and he never felt "comfortable" in the United States. For Emile, his interview subject's discomfort with an American identity complicated his notion of American-ness. Emile's interview subject spoke English, was a practicing Christian, and a successful entrepreneur-traits that he associates with being an American or with someone who wants to be American. Yet, as Emile learned, the subject felt isolated and uneasy in his adopted country. Feeling little connection to the country, Emile's interview subject was determined to return home and start life anew, even at the risk of lowering his standard of living or losing some wealth. ${ }^{32}$

Mena is an Indian American woman whose family is from Guyana. She also wanted to explore issues of American-ness and religious tolerance through the experiences of her husband, a survivor of the terrorist attacks of September 11, 2001.

\footnotetext{
${ }^{30} \mathrm{Jorge}$ video interview.

${ }^{31}$ Jorge, post-interview essay.

${ }^{32}$ Emile video interview.
} 
Mena and her husband are Muslims by faith. Mena's husband asserted his sense ofAmerican-ness through both the communal response of survivors on the day of the terrorist attacks and in reaction to the attack on him by other Muslims: "I feel more American after the tragedy of $9 / 11$... On that day it did not matter if you were black or white, short or tall, we were all American because every person helped each other."33 Mena's husband also connected his American-ness to his pervasive fear of Muslim extremists, based on the sense that "those guys [Islamic fundamentalist terrorists] don't consider me to be a real Muslim."34 As a result, his identity was shaped by community action, embrace, and sharing, as well as by exclusion and intolerance.

The sixth student, Reveca, sought to address the highs and lows of migration by interviewing her parents-immigrants from Pakistan - and contrasting their experiences with her own. Reveca's interview of her parents documented the "shock of arrival" for immigrants and the ambivalence or "rootless-ness" that some feel. ${ }^{35}$ Her father said that two of his daughters remained in Pakistan, making it difficult for him to help them whenever they needed assistance. Her mother remarked that the separation also challenged the sense of family cohesion. ${ }^{36}$ Reveca placed her own experiences of adjusting to American public schools and social settings within the context of her parents' struggles and found connections that she had not known existed.

Having watched or listened to the oral history interviews and read the postinterview essays, I assigned each student a grade according to the aforementioned criteria. Once I completed the grading, I turned my attention to assessing the overarching project.

\section{Findings}

The overall goals of using an oral history project to reinforce fundamental writing and critical thinking skills and to engage students were met through this experiment. The students benefitted from crafting their interview questions, connecting with their subjects, and drawing parallels between course themes and the oral history project. In this way, they clearly became engaged participants in their learning and, through their own efforts, came to fully understand the truism that a wonderful way to learn a subject

\footnotetext{
${ }^{33}$ Mena post-interview essay.

${ }^{34}$ Mena video interview.

${ }^{35}$ For example, see Mena Alexander, The Shock of Arrival: Reflections on Postcolonial Experience (Boston: South End Press, 1996).
}

${ }^{36}$ Reveca audio interview. 
is by immersing oneself in it. ${ }^{37}$ Thus, the oral history project proved to be exciting and thought-provoking for the students as well as for me. The research posed questions that are difficult to measure with scientific certainty, but the overarching project results indicate a positive outcome with regard to each of the questions posed. However, there are specific parts of the project that could be altered to improve results.

The answer to the first question- "Do students achieve a deeper level of learning as active participants?"--was a clear "yes." In nearly all cases, the students carried out research in material outside the classroom assignments in preparation for their interviews. Their preparation and execution of the interviews made palpable the themes from "Three Worlds." Their questions to the interview subjects and their responses upon reflection to the interview demonstrated an intimate knowledge of many of the issues and historical events raised in class. This seemed especially true in a comparison of the post-interview with the essay-based mid-term and final examinations of their classmates. Further, it seemed to support the general supposition that oral history interviews can be an effective means of introducing students to the excitement of historical research, scholarship, and analysis. ${ }^{38}$

The answer to the second question-"Can out-of-class learning strengthen a student's understanding of course material in a general survey course?"- -was less clear. Although the student volunteers seemed to gain a deeper grasp of some of the major topics in the course, their questions and post-interview writings did not illustrate a greater understanding of the details from each week's in-class assignments and lectures. To be fair, the students were handicapped by my insistence that they limit the scope of the interviews. Moreover, I failed to devise a means of measuring the depth of their specific knowledge; indeed, I allowed them to take part in the project in lieu of taking the final examination. A majority of the student volunteers did score higher than the class average on the other graded assignments (quizzes, reaction papers, and the midterm exam). It would be difficult to determine, however, whether those results were attributable to the oral history project or some other factor.

The answer to the third question- "Will students gain greater empathy for historical subjects as a result of conducting oral history interviews?"-is not empirically measurable based on this project, but student essays seem to reflect a deeper understanding of key course themes of citizenship and the effects of race,

3?"'If you want to learn something, read about it; if you want to understand something, write about it; if you want to master something, teach it." Aquarian Times (2007), 6(2); quote attributed to Yogi Bhajan.

${ }^{38}$ Jennifer V. Jackson and Mary E. Cothran, "Black Versus Black: The Relationships Among African, African American, and African Caribbean Persons," The Journal of Black Studies, 33:5 (May 2003), 576-604; Roger D. Long, "The Personal Dimension in Doing Oral History," The History Teacher, 24:3 (May 1991), 307-312. 
religion, and ethnicity on identity. ${ }^{39}$ The concepts of citizenship, migration, and exclusion were made concrete in ways that textual analysis and classroom discussion cannot achieve. Students drew connections between historical facts and contemporary issues such as mass incarceration and its impact on individual rights and communities. They saw parallels between historical religious persecutions and ongoing religious intolerance and mythology. They began to understand the importance of history to their own lives.

Most of the students displayed compassion for their subjects, as well as for the community at large. Jorge, for instance, informed me repeatedly that he would be proud if I showed his video interview in any public forum. He also expressed his willingness to speak about his life at any public event regarding immigration. His offers impressed me because he acknowledged in his post-interview essay that his parents had entered the country illegally and that he did not have a green card. Accordingly, his willingness to speak on behalf of other immigrants seems like some measure of empathy, as well as courage, because he was willing to expose himself to prosecution and deportation in order to enhance our notion of democracy. ${ }^{40}$

Idris expressed a sentiment similar to Jorge's. As a social work student, he was interested in the possibility of staging a public program at York regarding the lives of formerly incarcerated persons and the impact of incarceration and former-inmate reentry on communities like Southeast Queens. For her part, Reveca noted in her postinterview writing that, despite having lived in the U.S. for roughly a decade, she still felt "proudly Indian." Even though she came to America when she was seventeen, she did not feel "American" in large part because of the difficulties she and her parents faced either finding work or, in her case, getting an education. She did, however, express her delight at learning details about her parents' lives that she did not know until the interview, a serendipitous benefit of the project. ${ }^{41}$ Even if one looks back at Mena's interview of her 9/11 survivor-husband, this young man of South Asian descent

\footnotetext{
${ }^{39}$ Theresa A. Adkins-Coleman, "I'm Not Afraid to Come into Your World:' Case Studies of Teachers Facilitating Engagement in Urban High School English Classrooms," The Journal of Negro Education, 79:1 (Winter 2010), 41-53, 45.

${ }^{40}$ Jorge's courage foreshadowed a similar commitment by recent "Occupy" activist Pancho Ramos who was arrested in an Oakland, California, demonstration and detained because of his immigration status. See "Occupy Oakland Protester Pancho Ramos Stierle Faces Deportation After Arrest While Meditating," Democracy Now, November 18, 2011, www.democracynow.org.

${ }^{41}$ Reveca post-interview essay.
} 
articulated a form of democratic empathy when he said "we were all American because every person helped each other." ${ }^{42}$

As I ponder the project, I am ecstatic about the potential of oral history interviews to have a positive impact on subject-specific learning and building core skills but sobered by the challenges I face as I continue this line of exploration. First, it is clear that there is a need for continued study. The student volunteers from that spring's course form only a small sample from which to draw any strong conclusions. Second, I wonder whether I should require all of the students in a particular class to undertake an oral history interview in order to better determine its subtle strength as a tool for knowledge acquisition, interpretation, and empowerment. Third, I feel the need to refine my tools of evaluation, while keeping in mind that the assessment of an oral history interview for a grade in a course differs from the assessment of the oral history interview for the purpose of understanding the power of experiential learning.

In order to strengthen the project in the future, students might be asked to interview people different from themselves; in this regard, I could learn how their impressions changed, if at all, following the interview. In the current project, two of the six student volunteers interviewed family members, while a third had friends interview him. Of the remaining three students, all seemed to express some level of admiration for their subjects but only one, Joan, explicitly stated that the interview caused her to reexamine her own biases. Initially, I was disappointed by my observations. Yet, upon further reflection, it seems that the student volunteers demonstrated empathy in ways that I initially failed to consider. Even with these caveats, the project had merit.

At one level, the oral history project provided my students the opportunity to develop or hone important research skills that they could use in almost any class. At a second level, it allowed them to engage in critical analysis of issues and phenomena that they found compelling or relevant. It enhanced their basic mastery of the subject by making them participants in, rather than spectators of, history. ${ }^{43}$ As Jeffrey Merrick wrote, "the point, of course, is that ... humans make history not only as they live it but also when they write it and rewrite it, in light of later events or present concerns." ${ }^{44}$ At a third level, the oral history project allowed me to match my teaching style to the learning styles of many of my students. For some, this meant that they could excel in class through a "learning by doing" approach to the material, while for others it meant

\footnotetext{
${ }^{42}$ Mena video interview.
}

${ }^{43}$ Pattie Dillon, "Teaching the Past Through Oral History," The Journal of American History, 87:2
(2000), 602-605.

${ }^{44}$ Jeffrey Merrick, "July 14 and September 11: Historical Method and Pedagogical Method," The History Teacher, 39:2 (February 2006), 197-214. 
that their oral orientation was an asset rather than a hindrance to learning. ${ }^{45}$ Moreover, I felt comfortable that the project had shaken the students free from a quiet but critical chain on their intellectual growth.

Given the demographics of York College, most of my students see themselves as "subjects" of history in the sense that they spend their lives trying to survive the storms caused by large, seemingly incomprehensible forces over which they have no control. Moreover, like most college students, nearly all of them take an instrumentalist approach to their education, as demonstrated by the often posed question, "Professor, what do I need to do to get an A?" This approach to education tends to treat their degree as a tool by which they can reach some sanctuary through finding a career or at least a better-paying job. Consequently, many treat their elective courses like World History as a hurdle to be overcome in order to gain their degree rather than as opportunities for thoughtful exploration and personal enrichment. ${ }^{46}$

In addition, nearly all of them work-sometimes more than one job-or are parents (or both), meaning that they come to class with varying degrees of fatigue and stress. Thus, one of the greatest impediments to their learning is not who they are but where they are, specifically their position in the nation's social order. ${ }^{47}$ Perhaps Leslie Schuster described it best:

Classroom experiences [in which the teacher controls the process and materials of learning, among other things] suggest that there is far more behind my students' attitude towards the classroom and learning than weak analytical skills ... Moreover, research shows that the experiences of these working-class students, both inside and outside of the classroom, have negated the knowledge they bring to learning, demeaned their individual voices, and taught them to follow "the rules." The attitudes of our culture that disrespect working-class practices and voices and instead teach habits of deference further impede student engagement with the college material. As a result, working-class students have learned that doing well is

\footnotetext{
${ }^{45}$ Vazquez and Wainstien, "Instructional Responsibilities of College Faculty to Minority Students," 605607.
}

${ }^{46}$ See Ivory A. Toldson and Aviella Snitman, "Editor's Comment - Educational Parity and Economic Disparities: Correcting Education-Attainment Discrepancies among Black People in the United States," The Journal of Negro Education, 79:1 (Winter 2010), 1-5.

${ }^{47}$ See Peter C. Murrell, Jr., Race, Culture, and Schooling: Identities of Achievement in Multicultural Urban Schools (New York: Erlbaum, 2007); Joy DeGruy, Post Traumatic Slave Syndrome: America's Legacy of Enduring Injury and Healing (Oakland, CA: Uptone Press, 2005). 
predicated on minding the authority and denying much of their own world. ${ }^{48}$

Our experiences at York are similar to Schuster's and are compounded by the additional elements of race, gender, English language proficiency, and citizenship status. The oral history project proved a meaningful vehicle for trying to escape a powerful ideology that shapes students' learning as much as the instructor or the course material. In the process, I gained a useful tool to enhance student learning and another subject for critical examination over time. Thus, the success of the project was not only for the students but for me, too. ${ }^{49}$

\section{APPENDIX \\ INFORMED CONSENT and DEED OF GIFT \\ YORK COLLEGE DEPARTMENT OF HISTORY \& PHILOSOPHY JAMAICA, NEW YORK}

$\mathrm{I}$,

and (Interview Subject) residing at

hereby give to Dr. George White, Jr. in the Department of History \& Philosophy, York College-CUNY, Jamaica, New York, the tape (audio and/or video) recordings and any transcripts of my interview conducted on [date] at

[place of interview]. I understand that Dr. White and York College will use my oral history interview and any edited transcripts made from this interview for such historical and scholarly purposes as they see fit and that by this conveyance I relinquish:

1. All legal title and literary property rights which I have or may be deemed to have in said work;

2. All my right, title, and interest in copyright which I have or may have deemed to have in said work and more particularly the exclusive rights of reproduction, distribution, preparation of derivative works, public performance, and display. Right or reproduction and distribution will explicitly permit the posting and/or reproduction of edited interview

\footnotetext{
${ }^{48}$ Schuster, "Working-Class Students and Historical Inquiry," 163-164.

${ }^{49}$ See Chavella T. Pittman, "Exploring How African American Faculty Cope with Classroom Racial Stressors," The Journal of Negro Education, 79:1 (Winter 2010), 66-78.
} 
transcripts and audio or video tapes by Dr. White in classes, public forums, or on the Internet for use by scholars, students, and the general public.

I herein warrant that I have not assigned or in any manner encumbered or impaired any of the aforementioned rights in my oral memoir. The only conditions which I place on this unrestricted gift are: [none; if some, specify in writing]

\section{AGREED}

Interview Subject

\section{Date}

\section{AGREED}

Interviewer

\section{Date}

Dr. White and the Department of History \& Philosophy hereby accept the above described gift.

\section{AGREED:}

THE DEPARTMENT OF HISTORY \& PHILOSOPHY

By:

\section{Date}

George White, Jr., Assistant Professor of History 